\title{
The Role Of Student Performance Reviews In A Teacher Preparation Program: Can This Teacher Candidate BeSaved?
}

Nina G. Dorsch, (E-mail: ndorsch@niu.edu), Northern Illinois University

Diane H. Jackman, (E-mail: djackman@niu.edu), Northern Illinois University

\begin{abstract}
Teacher preparation programs assess students' knowledge, skills, and dispositions throughout the program. When concerns about student performance arise, the Student Performance Review is a vehicle for "saving” teacher candidates.
\end{abstract}

\section{INTRODUCTION}

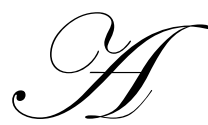

ssessment and accountability demands in teacher education clearly call for teacher preparation programs to be able to "separate out those who can teach effectively and responsibly from those who cannot" (Ginsberg \& Whaley, 2003, p. 169). The National Council for Accreditation of Teacher Education (NCATE) standards require teacher preparation programs to have in place systems to assess teacher candidate knowledge, skills, and dispositions at various points throughout the program. Presumably, candidates who do not meet standards at these assessment points would be subject to retention policy provisions that would lead to a probationary status in the program or dismissal from the program. Ginsberg and Whaley's (2003) survey of 50 colleges and universities found that $96 \%$ of the randomly-selected institutions had specific admission requirements and retention policies for their teacher preparation programs. Most frequently, retention policies relied on minimum grades in "professional" courses and/or maintenance of a minimum GPA. Fewer institutions (88\%) had policies that allow program or K-12 faculty to raise concerns about a candidate's potential as a teacher.

While retention criteria typically include academic performance and demonstration of professional competencies, a survey of American Association of Colleges for Teacher Education (AACTE) member institutions was conducted to determine other reasons programs would counsel teacher candidates to drop out of a teacher preparation program (Muir \& Leslie, 1990). Survey results indicate a variety of nonacademic conditions that are considered by teacher preparation programs, including personal, behavioral, legal, and physical issues or situations. Physical exceptionalities (e.g., conditions that affect the stamina required for teaching) and grooming were among the top five ranking at that time, with behavioral and legal issues claiming middle rankings, and personal circumstances contributing the final conditions. How retention criteria-academic, performance, or dispositional—are monitored varies across teacher preparation institutions and programs. Guffy and Mann (1999) report on the process by which teacher candidates' qualifications are monitored at West Texas A \& M University (WTAMU). All Division of Education faculty at WTAMU monitor student performance through use of a checklist of characteristics essential for effective teaching, faculty data are entered into a database and tracked for each student, and students whose ratings are of concern receive a letter identifying areas of concern and urging them to address the expressed concerns. If concerns continue, the teacher candidate meets with the performance assessment team. Guffy and Mann (1999) note that the process helps candidates recognize and work through problem areas and identifies those who are not suited to teaching, and those individuals are counseled out of the program.

Although counseling students out of a teacher preparation program serves to assure "quality control" in teacher preparation, such practices affect completion rates and times, a concern that prompted a Congressional request to the General Accounting Office (GAO) to examine what the U.S. Department of Education, states, and higher education institutions are doing to foster timely completion of the bachelor's degree. In the GAO report (2003), 
Ashby notes that states are publishing retention and graduation rates to assist potential students in making an informed higher education choice. Consequently, teacher preparation programs must balance the demand that teachers be highly qualified and the demand for retention and graduation rates that demonstrate broad accessibility of higher education.

At Northern Illinois University, the Department of Teaching and Learning (TLRN) in the College of Education houses teacher preparation programs at the undergraduate and graduate levels in early childhood education, elementary education, and special education, graduating more than 450 teacher candidates each year. In TLRN, concerns arising from coursework or clinical experiences are dealt with through the Student Performance Review (SPR) process. This study examines the SPR process as it occurred for 23 teacher candidates over the 2002-2003 and 2003-2004 academic years, with particular attention to how the SPR process balances the demands for quality teacher preparation and high program retention rates.

\section{THE STUDENT PERFORMANCE REVIEW PROCESS}

The NIU Department of Teaching and Learning (TLRN) of the College of Education employs the following procedures for reviewing the progress and performance of students enrolled in teacher education programs (Policies and Procedures Handbook, 2004).

A Student Performance Review (SPR) can be initiated by any of the following actions:

- A course instructor completes and files a Teacher Education Deficiency Form because a student's performance or behavior raises concern about the student's progress and/or suitability for teacher education due to deficiencies in academic performance, professional behavior, or attitude. The student is notified and given the opportunity to sign the form indicating receipt. The instructor submits the form to the Student Recruitment and Retention Committee.

- A student's performance is rated as "unsatisfactory" or "poor" on an Early Clinical Experience Evaluation Form. The student is notified and given the opportunity to sign the form indicating receipt. The instructor submits the form to the Student Recruitment and Retention Committee.

- University supervisors complete a Clinical Observation/Visitation Form each time they observe a student in a clinical setting. If a university supervisor indicates on that form that a student's behavior or performance is perceived to be inadequate or unprofessional, or raises concerns on the part of the cooperating teacher and/or school district personnel, that supervisor must also complete a Teacher Education Deficiency Form. The supervisor submits the form to the Student Recruitment and Retention Committee.

The TLRN faculty has established a professional procedure with regard to SPRs. A committee composed of faculty members hears each case and makes an individualized determination regarding the student's status in the teacher education program. The composition of the committee includes voting members (two faculty from the student's major and one from the department at large) and non-voting members (the student's advisor, the department chair's designee). The student's advisor may be called upon to provide information about the student's academic record. The department chair's designee serves to assure that SPR processes as set forth in the SPR handbook are observed. A member of the Student Recruitment and Retention Committee convenes and facilitates the SPR meeting. At least 10 days prior to the SPR, a letter is sent to the student by certified mail, notifying the student of the date, time and location $\mathrm{f}$ the SPR meeting; providing a copy of the deficiency report (and any supporting documents); and outlining the general procedures of the SPR meeting. The letter also informs the student that $\mathrm{s} / \mathrm{he}$ is required to meet with his/her advisor prior to the meeting and that s/he should be prepared to respond to a question asked in all SPR meetings: What would you do differently to insure a successful outcome if allowed another opportunity to enroll in the course or clinical in question? 
In conducting a Student Performance Review, the chairperson of the SPR committee follows these general procedures:

- Introductions of everyone present

- Chairperson explains the purpose of the meeting, the possible outcomes, and the procedures to be followed, including procedures for recording the meeting (e.g., audiotape)

- $\quad$ The course instructor or university clinical supervisor who initiated the SPR summarizes the situation from his or her vantage point

- The student summarizes the situation from his or her vantage point, adding to what the instructor or supervisor has reported, noting areas of disagreement, etc. One person of the student's choosing may accompany him or her. This person does not present information directly to the committee, but may consult with the student during the meeting.

- $\quad$ Committee members ask questions of the instructor or supervisor and the student in order to fully understand the situation and implications of various possible outcomes.

- $\quad$ The student and the instructor or supervisor are asked to leave the room.

- Committee members discuss the situation and come to consensus about the course of action, requisite followup, remediation plans, etc. When consensus cannot be reached, a vote is taken.

- The student and instructor or supervisor are brought back into the room, as appropriate and desired. The chairperson explains the proposed course of action, answers questions, summarizes follow-up plans, and so on.

- $\quad$ The chairperson explains that the outcomes will be formally written up and circulated to everyone present and to the advising office, clinical office, and dean's office. This report of the SPR outcomes includes the following: committee members and others present at the meeting, description of the presenting problem, summary of the discussion that ensued, and committee decision and recommendations, including any necessary follow-up, remediation plans, requirements of the student, timelines, etc.

The outcomes of a SPR may include, but are not limited to, the following:

- $\quad$ The student may be informed that the written concern(s) do not warrant further action; the student will be allowed to proceed in the program.

- The student may be placed on "professional probation" with specific requirements for remediation. The nature and scope of necessary progress reports will be determined by the SPR committee. The student is responsible for ensuring that the progress reports specified are submitted to the chair of the SPR committee by the designated time.

- $\quad$ The student may be dropped from the initial certification program.

The reports generated by the SPR process for the 23 SPRs conducted in 2002-2003 and 2003-2004 constitute the primary data set for this paper.

\section{METHODOLOGY}

This study employed a content analysis approach to the examination of the documents generated in 23 SPR cases. In this approach to document analysis, content analysis is "...a research methodology that utilizes a set of procedures to make valid inferences from the text" (Weber, 1985, p. 4). The content analysis of SPR reports from a two year period included the following initial categories: demographic characteristics (teacher candidate program major and gender), point in the program in which the concern appeared, nature of the presenting concern, SPR discussion threads, and SPR decision. Within each of these categories, data were examined to discern patterns relevant to the following questions:

- What is the nature of concerns about student performance that arose in TLRN during the two-year period?

- What decisions resulted from the SPR process during the two-year period?

- What considerations guided the SPR decision? 


\section{FINDINGS}

Findings regarding demographics, point in the program in which the concern appeared, nature of the presenting concern, and SPR decision are summarized in Table 1 and Table 2 for the 2002-2003 and 2003-2004 academic years, respectively.

Generally, the proportion of teacher candidates referred for an SPR in the three teacher preparation majors reflects the proportion of the overall enrollment in the three majors. For example, 56.5\% of all SPRs over the twoyear period involved candidates in the elementary education program whose total enrollment is approximately $60 \%$ of all teacher candidates in the department. However, the percentage of special education candidates referred for an SPR in 2003-2004 was disproportionate to the $25 \%$ proportion of special education candidates in all teacher preparation programs in the department.

Candidates referred for an SPR, like the overall population of teacher candidates in the department, were overwhelmingly female. In terms of percent, the nearly $18 \%$ of SPR candidates that were male exceeds their representation in the overall teacher candidate population. Yet, an absolute number of four males over a two-year period does not permit drawing any conclusions about the presence (or absence) of gender bias in SPR referrals.

Table 1 2002-2003 SPRs

\begin{tabular}{|c|c|c|c|c|c|}
\hline Candidate & Gender & Major & Program point* & Concern & SPR decision \\
\hline 1 & $\mathrm{~F}$ & Elementary & $2^{\text {nd }}$ prof. sem. & Academic & $\begin{array}{l}\text { Retake courses, referral for } \\
\text { assistance }\end{array}$ \\
\hline 2 & $\mathrm{~F}$ & Elementary & $2^{\text {nd }}$ prof. sem. & Academic & Continue in program with support \\
\hline 3 & $\mathrm{~F}$ & Elementary & Student teaching & $\begin{array}{l}\text { Professionalism, } \\
\text { classroom management }\end{array}$ & Repeat student teaching \\
\hline 4 & $\mathrm{~F}$ & Elementary & $1^{\text {st }}$ prof. sem. & Academic Attendance & $\begin{array}{l}\text { Candidate withdrew from } \\
\text { program }\end{array}$ \\
\hline 5 & $\mathrm{~F}$ & Special Ed & $2^{\text {nd }}$ prof. sem. & Academic & Continue on probation \\
\hline 6 & M & Elementary & $1^{\text {st }}$ prof. sem. & $\begin{array}{l}\text { Academic Clinical } \\
\text { performance }\end{array}$ & $\begin{array}{l}\text { Repeat courses with remediation; } \\
\text { referral for support services }\end{array}$ \\
\hline 7 & $\mathrm{~F}$ & Elementary & $2^{\text {nd }}$ prof. sem. & Academic & $\begin{array}{c}\text { Repeat courses; support } \\
\text { requirement }\end{array}$ \\
\hline 8 & $\mathrm{~F}$ & $\begin{array}{c}\text { Early } \\
\text { Childhood }\end{array}$ & Student teaching & $\begin{array}{l}\text { Clinical performance in } \\
\text { repeat student teaching }\end{array}$ & Dismissal from program \\
\hline 9 & M & Elementary & $\begin{array}{l}1^{\text {st }} \text { prof. sem. } \\
\text { clinical }\end{array}$ & Disposition & $\begin{array}{c}\text { Dismissal from program* } \\
\text { (Appealed: allowed to repeat } \\
\text { clinical) }\end{array}$ \\
\hline 10 & $\mathrm{~F}$ & $\begin{array}{c}\text { Special } \\
\text { Education }\end{array}$ & Student teaching & $\begin{array}{c}\text { Lesson planning; } \\
\text { Classroom management }\end{array}$ & $\begin{array}{l}\text { Repeat student teaching with } \\
\text { remediation plan }\end{array}$ \\
\hline
\end{tabular}

* Programs are sequenced in a series of "professional semesters." The first professional semester generally occurs at the fifth or sixth semester of a four year university experience.

While 50\% of the SPRs in 2002-2003 involved academic concerns, only one of thirteen SPRs held in 2003-2004 focused on academic performance. The decrease can be seen as a by-product of the state's requirement that individuals pass the state's "enhanced" basic skills test prior to admission to a teacher certification program and to the programs' increasing minimum GPA requirements. Both the elementary and special education programs moved to minimum GPA requirements of 3.0, and the early childhood program entry GPA requirement was set at 2.75. In fact, academic performance concerns seemed to arise primarily from attendance issues and timely submission of assignments rather than a concern about student ability. 
Table 2 2003-2004 SPRs

\begin{tabular}{|c|c|c|c|c|c|}
\hline Candidate & Gender & Major & Program Point* & Concern & SPR decision \\
\hline 1 & $\mathrm{~F}$ & Special Ed & Student teaching & $\begin{array}{c}\text { Classroom } \\
\text { management; School } \\
\text { terminated placement }\end{array}$ & $\begin{array}{c}\text { Choice: New major } \text { or remediation } \\
\text { followed by repeat student teaching } \\
\text { with performance contract }\end{array}$ \\
\hline 2 & $\mathrm{~F}$ & Elementary & $2^{\text {nd }}$ prof. sem. & $\begin{array}{l}\text { Academic (non- } \\
\text { required course) }\end{array}$ & Repeat course \\
\hline 3 & $\mathrm{~F}$ & Elementary & Student teaching & $\begin{array}{l}\text { Planning, classroom } \\
\text { management, } \\
\text { assignments not } \\
\text { completed }\end{array}$ & $\begin{array}{c}\text { Repeat student teaching with added } \\
\text { observations and prohibition on } \\
\text { external employment }\end{array}$ \\
\hline 4 & $\mathrm{~F}$ & Elementary & Student teaching & $\begin{array}{c}\text { Planning, time } \\
\text { management }\end{array}$ & $\begin{array}{l}\text { Candidate decision to withdraw from } \\
\text { program }\end{array}$ \\
\hline 5 & $\mathrm{~F}$ & Special Ed & $1^{\text {st }}$ Clinical & $\begin{array}{l}\text { Lesson planning; } \\
\text { Dispositions }\end{array}$ & Dismissal based on candidate desire \\
\hline 6 & $\mathrm{~F}$ & $\begin{array}{l}\text { Early } \\
\text { Childhood }\end{array}$ & Student teaching & $\begin{array}{l}\text { Planning \& preparation } \\
\text { skills (weak earlier } \\
\text { clinical) }\end{array}$ & $\begin{array}{l}\text { Repeat early clinical; referred for } \\
\text { counseling }\end{array}$ \\
\hline 7 & $\mathrm{~F}$ & Special Ed & Student teaching & $\begin{array}{c}\text { Lesson planning \& } \\
\text { classroom management }\end{array}$ & $\begin{array}{l}\text { Referred for assistance with learning } \\
\text { disability; repeat student teaching }\end{array}$ \\
\hline 8 & $\mathrm{~F}$ & Elementary & Student teaching & $\begin{array}{l}\text { Placement terminated } \\
\text { by school; lack of } \\
\text { content knowledge, } \\
\text { concern about } \\
\text { language/usage } \\
\end{array}$ & $\begin{array}{l}\text { Repeat student teaching with regular } \\
\text { conferences with supervisor }\end{array}$ \\
\hline 9 & $\mathrm{~F}$ & Special Ed & Student teaching & $\begin{array}{c}\text { Lesson planning, } \\
\text { classroom management }\end{array}$ & $\begin{array}{l}\text { Extended placement with journal } \\
\text { required }\end{array}$ \\
\hline 10 & $\mathrm{~F}$ & Elementary & Student teaching & $\begin{array}{l}\text { Placement terminated } \\
\text { by school; planning/ } \\
\text { communication issues }\end{array}$ & $\begin{array}{l}\text { Extended observation followed by } \\
\text { repeat student teaching }\end{array}$ \\
\hline 11 & $\mathrm{~F}$ & Special Ed & Early clinical & $\begin{array}{l}\text { Lesson planning, } \\
\text { attitude, attendance }\end{array}$ & $\begin{array}{l}\text { Referred for support for learning } \\
\text { disability; repeat clinical; weekly } \\
\text { self-evaluation }\end{array}$ \\
\hline 12 & M & Special Ed & Student teaching & $\begin{array}{l}\text { Placement terminated } \\
\text { by school; legal and } \\
\text { disposition issues }\end{array}$ & $\begin{array}{l}\text { Repeat student teaching in another } \\
\text { school district }\end{array}$ \\
\hline 13 & M & Elementary & Student teaching & $\begin{array}{l}\text { Classroom } \\
\text { management; language } \\
\text { use concerns; } \\
\text { disposition }\end{array}$ & Dismissal from program \\
\hline
\end{tabular}

* Programs are sequenced in a series of "professional semesters." The first professional semester generally occurs at the fifth or sixth semester of a four year university experience.

Over half of the SPR referrals occurred in conjunction with the student teaching experience. This proportion can be seen as disconcerting - supposedly, significant concerns about candidate performance would be detected in early clinical (pre-student-teaching) semesters. A closer examination of the reasons for SPR referrals during student teaching reveals a possible dimension of student performance that might ameliorate this apprehension. The concerns arising during student teaching tended to center on lesson planning and classroom management. This is not surprising - in early clinicals, candidates do not assume total lesson planning duties for an extended period as they do in student teaching. When candidates assume that responsibility, issues of time management and macro curriculum planning perspectives surface, issues beyond knowledge and skill in developing individual lesson or unit plans that are designed well in advance and implemented in classrooms over a relatively short period of time. The ability to plan over a longer period of months, rather than weeks, appears to be a skill that is distinct from the ability to generate lesson and unit plans on paper for a methods course or the ability to implement a single lesson or unit during an early clinical experience. Similarly, in early clinicals the cooperating teacher is consistently in the classroom to assist with 
classroom management, and the early clinical experiences occur in three-week periods (elementary education) or in a two-days-a-week-for-several-weeks format (special education). In those early clinical situations, establishing their own classroom management plans is not a pressing requirement or expectation for teacher candidates.

The SPR decision for the vast majority of cases in the two-year period involved candidates' repeating courses or clinical/student teaching experiences, usually with a remediation plan or some form of support to enhance the likelihood that the candidate would be successful in that repetition. For six cases, the result of the SPR was the candidates' discontinuation in their teacher preparation programs. The SPR process appeared to be a catalyst for three of these candidates' decisions to withdraw from the program (two instances) or request dismissal from the program (one instance). Consequently, only three of the 23 SPRs resulted in a dismissal decision.

The discussion threads that led to the repeating/remediation or dismissal situations speak to how the SPR process balances the demands for quality teacher preparation and high program retention rates. Central to the discussion threads in all of the SPRs was the advice given to candidates in the notice of the SPR to be prepared to answer a question about what the candidate would do differently if allowed to continue in program. The desire of SPR committee members seemed to be to promote reflective self-evaluation (e.g., requirements for journaling, extended observation, self-evaluations) and an internal locus of control (assuming responsibility for one's behaviors). If candidates initially were unable to articulate what they would do differently in the future, committee members posed probing questions to encourage reflection, assist in identifying and solving problems, and suggest potential structures for remediation or support. In seeking to assist candidates in identifying the source(s) of undesirable behavior or performance, committee members elicited information that assisted in devising plans that would permit the candidates to continue in the program. Many of the SPR reports included the statement that "committee members asked questions to more fully understand the situation." Often candidates were asked "what additional resources [s/he] would seek out if given another opportunity." For example,

- In the situation of a single mother of children with special needs, "Committee members agreed that Ms. has been experiencing an inordinate amount of stress and that reducing some of her coursework would be beneficial." Careful schedule planning, a referral to university counseling services, and suggested avenues to obtaining a loaned computer were all part of the plan in which one candidate repeated courses that she was in danger of failing.

- $\quad$ A candidate experiencing an unplanned pregnancy (with morning sickness and sleeplessness) was asked about how she would "manage a major life transition during student teaching." A consultation with University Resources for Women and creation of a student teaching calendar that would not commence until at least six weeks after the anticipated delivery date (and then only with a doctor's release) became part of the SPR decision.

- $\quad$ A non-traditional student who attempted to maintain a job while student teaching to pay for her daughter's wedding that she was planning during student teaching "acknowledged that she was doing too much, and as a result her student teaching suffered." The decision to permit this candidate to continue in the program for another student teaching experience seemed to be based on the conclusion that the candidate "accepted responsibility for her shortcomings" and stated that she "would be more focused, spend ample time planning her lessons, and be all round prepared for her classes."

For some students, those for whom the SPR decision resulted in dismissal, the discussion threads seeking to understand the situation and identify resources necessary to support future success did not generate the desired results.

- "Clear documentation was apparent that had been given more than one chance to complete her field experience successfully." In this case, concern about being "very, very negative" in the way the candidate talked about her cooperating teacher, and that she had not been "proactive in responding" to past concerns or "following through with communication with her advisor." The committee concluded that "there is insufficient evidence that __ will succeed if given a third try at this experience."

- $\quad$ "Mr. ___ demonstrated no ownership of any misgivings that stemmed from student teaching . . . Rather, he was defensive and angry, placing blame on others." The committee concluded that an opportunity to repeat 
student teaching in this case would not lead to a substantially different outcome and dismissed the candidate from the program.

Responding to the important question of what they would do differently involved more than expressing regret or accepting responsibility for an unsatisfactory performance. Committee members appeared to be looking for critical self-reflection and problem-solving skills that they believed are essential to becoming an effective teacher. Like Wiseman, Cooner and Knight (1999), committee members seemed to feel that "the reflective processing of the experiences" is an important part of a teacher education program (p. 23). Their articulated reasons for their decisions were aligned with multiple standards frameworks (INTASC, National Board for Professional Teaching Standards, and Illinois Professional Teaching Standards for All Teachers) that stress reflection, problem-solving, communication, and decision-making skills as integral to effective teaching.

\section{DISCUSSION}

The nature of concerns raised in the SPR process points to considerations for teacher education program retention policies. NIU teacher education programs are seeing increased numbers of non-traditional students, students who must work full time (or nearly full time) to pay for their higher education, and students with a variety of personal and emotional problems. Having college or university resources to address these needs and to support these students are necessary to their success. Student teaching, in particular, is a stressful time in which the press of sustained and consistent instructional and classroom management performance can lead to candidates' feeling overwhelmed and frustrated. To some extent, the regular seminars that supervisors conduct with student teachers can be a forum for venting such feelings, but that forum was not sufficient for at least three of the candidates referred for SPRs during the period considered in this paper. Time management, a challenge for all teachers, was a particular challenge for many of the NIU SPR candidates. Teacher education programs might consider incorporating time management practice and skills more explicitly in their programs.

In the SPR process, committee members were as concerned with candidate dispositions as with candidate knowledge and skills, reflecting the emphasis on all three areas within the National Council for the Accreditation of Teacher Education (NCATE) standards. Maintaining program integrity and assuring that candidates meet standards were important considerations in the SPR process. Yet decisions were based on a "process on concretization rather than one of abstraction" (Noddings, 1984, p. 8). Committee members wanted to understand each situation in its uniqueness, to "reduce the pain, to fill the need, to actualize the dream" (Noddings, 1984, p. 14). Adopting an ethic of care in what they regarded as a moral decision-making process, committee members balanced the needs of candidates with the needs of the teaching profession. Caring for candidates did not, however, mean making excuses for or eliminate a "tough love" stance with candidates. A caring approach in an SPR involves an attitude for "screening in" rather than "screening out" candidates. It is through "screening in" candidates-assisting them in reflection and problem-solving, providing remediation plans, and directing them to resources for assistance and support-that the faculties in TLRN balance the demands for quality teacher preparation and high program retention rates.

\section{REFERENCES}

1. Ashby, C.M. (2003). College completion: Additional efforts could help education with its completion goals. Report to Congressional requesters. General Accounting Office, Washington, D.C. (GAO-03-568).

2. Ginsberg, R. \& Whaley, D. (2003). Admission and retention policies in teacher preparation programs: Legal and practical issues. The Teacher Educator (38):3, 169-189.

3. Guffy, T. \& Mann, G. (1999). Performance assessment team: A retention program revisited. Paper presented at the Annual Meeting of the Association of Teacher Education, Chicago, IL, February 13-17, 1999.

4. Muir, S.P. \& Leslie, S.C. (1990). Non-academic criteria: Accountability in pre-service teacher education. Paper presented at the Annual Meeting of the American Association of Colleges for Teacher Education, Chicago, IL, March 28-31, 1990.

5. Noddings, N. (1984). Caring: A feminine approach to ethics and moral education. Los Angeles: University of California Press.

6. $\quad$ Policies and procedures handbook: Student performance reviews and grade appeals. www.cedu.niu.edu/ tlrn. Accessed November 12, 2004. 
7. Weber, R. P. (1985). Basic Content Analysis. Beverly Hills, CA: Sage Publications.

8. Wiseman, D. L., Cooner, D. D., \& Knight, S. L. (1999). Becoming a teacher in a field-based setting. Belmont, CA: Wadsworth Publishing Company.

\section{NOTES}

